Vol. 19 (2010): 173-183.

\title{
Nitrogen fertilization and yield formation of potato during a short growing period
}

\author{
Leo Mustonen*, Esa Wallius and Timo Hurme \\ MTT Agrifood Research Finland, Plant Production Research, FIN-31600 Jokioinen, Finland \\ *e-mail:leo.mustonen@mtt.fi
}

The effects various rates of nitrogen application on accumulation of dry matter and nitrogen in potato (Solanum tuberosum L.) were studied during a short growing period of 140-180 days, at MTT Agrifood Research Finland in 2000-2001. The treatments were 0,60 and $120 \mathrm{~kg} \mathrm{~N} \mathrm{ha}^{-1}$ and the potato cultivars tested were Van Gogh and Nicola. Four successive harvests were made during the course of the experiment to monitor changes in the accumulation of dry matter and nitrogen over the season. Applications of nitrogen substantially increased haulm dry matter accumulation and to an even greater extent their nitrogen contents. The highest dry matter values were generally registered at $120 \mathrm{~kg} \mathrm{~N} \mathrm{ha}^{-1}$. Dry matter and nitrogen content of haulms started to decline during the later part of season and most nitrogen was relocated to tubers. The results suggest that an application of only $60 \mathrm{~kg} \mathrm{~N} \mathrm{ha}^{-1}$ was sufficient to promote rapid canopy development and there were only small reductions in dry matter and nitrogen accumulation until late in the season when the canopy started to senesce as nitrogen supply diminished. Tuber yield, plant dry matter and nitrogen accumulation at maturity were related to crop nitrogen supply. Although application of the high rate, 120 $\mathrm{N} \mathrm{kg} \mathrm{ha}^{-1}$, resulted in a significant increase in dry matter accumulation, this was not reflected in the profit because the higher nitrogen application reduced dry matter content of tubers by $2.6 \%$ in 2000 and by $1.1 \%$ in 2001 relative to the use of $60 \mathrm{~kg} \mathrm{~N} \mathrm{ha}^{-1}$. Apparent fertilizer nitrogen recovery values on a whole plant basis ranged from 53 to $75 \%$. The proportion of fertilizer recovered in tubers clearly declined with increase in nitrogen supply.

Key-words: Solanum tuberosum, nitrogen fertilization, dry matter accumulation, nitrogen uptake, nitrogen recovery 
Mustonen, L. et al. Nitrogen fertilization and yield formation of potato

\section{Introduction}

Intensive potato (Solanum tuberosum L.) cultivation demands an adequate supply of nutrients to promote high yield and high quality. The nitrogen sources in the soil comprise the mineral nitrogen initially available in the soil, that which becomes available through mineralization and the external supply of $\mathrm{N}$ fertilizer. Soil factors, including water status, temperature, organic matter content and manure use, all impact on the turnover of nitrogen (Jarvis et al. 1996). In addition, average soil mineral nitrogen concentration appears to show substantial variation between years. The complex behaviour of nitrogen in the soil makes it difficult to forecast the amount needed by a crop, and it cannot be predicted at the beginning of the growing season. Since the growing period in northern conditions is short (140-180 days), the application of fertilizer nitrogen must be balanced between the potential yield of the crop and the intended harvest date so as to minimize $\mathrm{N}$ losses to the environment (Biemond and Vos 1992, Kuisma 2002). Nitrogen application in excess of the needs of the crop causes overproduction of foliage, resulting in late senescence (Millard and Marshall 1986). Under conditions of high nitrogen supply the risk of nitrate losses from the potato root zone increases, resulting in nitrate contamination to groundwater on the sandy soils typical for potato cultivation (MacDonald et al. 1997). In Finland it is common practice to provide all the $\mathrm{N}$ fertilizer at planting, and a split application has been found to be of no benefit to yield compared with a single dose (Kuisma 2002). Moreover, only a very small proportion of the main cropping area receives any input of organic manure.

The official fertilizer recommendations in Finland are based on climatic zone, organic matter content of the soil, potato cultivar and yield forecast. However, the national environmental legislation and support programme contains regulation and base limits for nitrogen application to all major crops. The recommendations for nitrogen fertilization of potatoes are rather low, $60-120 \mathrm{~kg} \mathrm{~N} \mathrm{ha}^{-1}$, according to their exact nitrogen requirements (Kuisma 1995, Mustonen 2004). Farmers are permitted to apply more nitrogen if there is good reason to expect high yields and high quality, to a maximum total application of $120 \mathrm{~kg} \mathrm{ha}^{-1}$, comprising both mineral fertilizers and animal manure. Maximum yield is not always attained because of current limits on total nitrogen application rates and limitations related to environmental concerns.

Some potato cultivars appear to be able to take up more nitrogen than others. Firman and Allen (1988) and Firman and Allen (1995) examined the effects of nitrogen fertilizer on potato growth of several contrasting varieties and suggested that indeterminate cultivars may have a smaller nitrogen fertilizer requirement than determinate cultivars. Cultivar differences in nitrogen requirement were related to differences in root systems between cultivars. Similarly Sattelmacher et al. (1990) found differences in nitrogen requirements between two cultivars related to root morphology. Also Zebarth et al. (2003) reported lower nitrogen use efficiency in early maturing cultivars compared with mid-season and late-maturing cultivars. The physiological basis of genotypic variation in nitrogen requirements of potato cultivars is not fully understood.

The objective of this study was to quantify the relationship between nitrogen supply and changes during the season in the accumulation of dry matter and nitrogen. More information was also sought on nitrogen use efficiency and the effect of nitrogen rate on partitioning of dry matter and nitrogen accumulation.

\section{Material and methods}

Experiments were conducted in 2000 and 2001 at MTT Agrifood Research Finland, Plant Production Research, Jokioinen, $\left(60^{\circ} \mathrm{N}\right)$. The experimental layout for trials harvested at maturity was a split-plot design of four replicate blocks. Nitrogen fertilization was arranged in main plots and potato cultivars in the subplots. The fertilizer treatments were 0,60 and $120 \mathrm{~kg} \mathrm{~N} \mathrm{ha}^{-1}$. Cultivars Van Gogh and Nicola are widely grown table potato cultivars of similar maturity class. The soil was light sandy soil high in organic matter typical of soils for potato cultivation in 


\section{AGRICULTURAL AND FOOD SCIENCE}

Vol. 19 (2010): 173-183.

Finland. Previous crop in rotation was spring barley (Avena sativa L.).

According to the local practice, the nitrogen, as ammonium nitrate $(27 \% \mathrm{~N})$, at $60 \mathrm{~kg} \mathrm{~N}^{-1}$ and $120 \mathrm{~kg} \mathrm{~N} \mathrm{ha}^{-1}$, was placed in rows $5 \mathrm{~cm}$ below and $10 \mathrm{~cm}$ to each side of the seed tubers at planting. All plots received potassium sulphate $(42 \% \mathrm{~K})$ and superphosphate $(9 \% \mathrm{P})$ broadcast before planting at a rate $45 \mathrm{~kg} \mathrm{P} \mathrm{ha}^{-1}$ and $180 \mathrm{~kg} \mathrm{~K} \mathrm{ha}^{-1}$ based on soil analysis. The trial field was ploughed in the autumn and prepared by tine cultivating to $15 \mathrm{~cm}$ three days before planting. Pre-sprouted seed potato was planted with a semi-automatic planter at $5 \mathrm{~cm}$ depth and a within-row spacing of $25 \mathrm{~cm}$. The potato was grade $40-45 \mathrm{~mm}$ certified seed. The experiments were established on May 18, 2000 and May 21, 2001. A subplot consisted of two rows $(1.5 \mathrm{~m})$ by $14 \mathrm{~m}$ for each plot, with one extra row acting as a guard row between main plots. Weeds and diseases were controlled using standard cultivation practices for the region and crops were practically free from both. Trials were harvested with a small harvester without haulm killing. No irrigation was applied.

Soil samples were taken shortly before planting to record the amount of residual mineral nitrogen from $0-15$ and 15-30 cm depths. Samples were kept frozen until analyzed. Soil water content was determined as weight loss from the samples by drying them overnight at $105{ }^{\circ} \mathrm{C}$. Soil samples were analyzed by extracting with $2 \mathrm{M} \mathrm{KCl}$ and using a Scalar Auto-analyser to determine nitrate $\mathrm{NO}_{3}-\mathrm{N}$ and ammonium $\mathrm{NH}_{4}^{+}$-N. Mineral nitrogen content of soil was determined as the sum of extracted nitrate and ammonium.

Plant dry matter and nitrogen accumulation were determined based on whole plant sampling four times during each growing season. Twelve plants were collected by hand from two rows in each plot and two plants were left as guard plants between sampling dates. Sampling dates were 1) 30 days after emergence (DAE), 2) 45 DAE, 3) 60 DAE and 4) 80 DAE. In 2000 there were no tubers at the first early sampling date 30 days after emergence. At final harvest haulms were cut at the soil surface. Plants were partitioned into tubers and haulms and further divided into leaves and stems. All plant samples were dried overnight at $105{ }^{\circ} \mathrm{C}$ for dry matter determination and at $60{ }^{\circ} \mathrm{C}$ for nitrogen analysis using a LECO FP 428 automatic analysis system. Potato nitrogen uptake at different harvest dates was calculated from measured values by multiplying dry matter of the tuber yields and above-ground parts by the corresponding nitrogen concentration.

Apparent fertilizer nitrogen recovery in the tubers is a measure of the efficiency of uptake of nitrogen applied as fertilizer. It is defined as: ARN $(\%)=\left[\left(\mathrm{NU}_{+\mathrm{N}}\left(\mathrm{kg} \mathrm{N} \mathrm{ha}^{-1}\right)-\mathrm{NU}_{-\mathrm{N}}\left(\mathrm{kg} \mathrm{N} \mathrm{ha}^{-1}\right)\right] /[(\right.$ fertilizer $\mathrm{N}$ applied $\left.\left(\mathrm{kg} \mathrm{N} \mathrm{ha}^{-1}\right)\right] \times 100$, where $\mathrm{ARN}$ is apparent fertilizer $\mathrm{N}$ recovery, $\mathrm{NU}_{+\mathrm{N}}$ is the tuber $\mathrm{N}$ content for a given fertilizer $\mathrm{N}$ treatment and $\mathrm{NU}_{-\mathrm{N}}$ is the tuber $\mathrm{N}$ content for the unfertilized control treatment. In these calculations it is assumed that both control and nitrogen fertilized plots absorbed the same amount of soil nitrogen. A possible source of error is that roots stimulated by fertilizer application may also take up some more nitrogen

The data for total dry matter, foliage dry matter, total content of nitrogen, nitrogen content of foliage and tuber dry matter content were analysed separately for 2000 and 2001. In the analyses, nitrogen fertilisation was considered as a main-plot factor, cultivar as a subplot factor, sampling date after emergence as a repeated measure and replication as a blocking factor. Repeated measurements from the same experimental plot were correlated, which was taken into account in the statistical models through appropriate covariance structures. The statistical model thus was:

$y_{i j k l}=\mu+\beta_{i}+n_{j}+\varepsilon_{i j}+c_{k}+(n c)_{j k}+\delta_{i j k}+d_{l}$ $+(\beta d)_{i l}+(n d)_{j l}+\theta_{i j l}+(c d)_{k l}+(n c d)_{j k l}+\gamma_{i j k l}$,

where $\mu$ is constant intercept, $\mathrm{n}_{j}, c_{k},(n c)_{j k}, d_{l},(n d)$ ${ }_{j l},(c d)_{k l}$ and $(n c d)_{j k l}$ are fixed main and interaction effects for the nitrogen fertilisation $(n)$, cultivar $(c)$ and sampling date $(d)$. The $\beta_{i}$ is the random effect for block $i$, and $\varepsilon_{i j}$ and $\delta_{i j k}$ are random main plot and subplot error effects, all mutually independent with variances $\operatorname{var}\left(\beta_{i}\right)=\sigma_{\beta}^{2}, \operatorname{var}\left(\varepsilon_{i j}\right)=\sigma_{\varepsilon}^{2}$, and $\operatorname{var}\left(\delta_{\mathrm{ijk}}\right)=$ $\sigma_{\delta}^{2}$. The $(\beta d)_{i l}$ represents the random time-specific contribution for block $i$, and $\theta_{i j l}$ and $\gamma_{i j k l}$ represent random time-specific main plot and subplot error effects (Gumpertz and Brownie 1993). The harvest at 
Mustonen, L. et al. Nitrogen fertilization and yield formation of potato

maturity data (tuber yield, tuber dry matter yield, dry matter content and nitrogen uptake) were recorded only once each year. However, the data from both years were analysed together, so year was considered as the repeated measure in this analysis.

For all the models mentioned above, REML was used as the estimation method and degrees of freedom were calculated using the Kenward-Roger method (Kenward and Roger 1997). The models were fitted using the MIXED procedure of SAS 9.2 (SAS Institute Inc., Cary, NC, USA). Pairwise comparisons were performed using two-sided $t$ type tests. Model assumptions were checked using appropriate graphs. For the tuber dry matter content in 2000, base-10 logarithmic transformation was applied to the data because of unequal variances on the original scale.

\section{Results}

\section{Weather conditions and soil nitrogen availability}

Weather data for May - August from the Jokioinen weather station of the Finnish Meteorological Institute are given in Table 1. The mean air temperature during the growing season was $14.3{ }^{\circ} \mathrm{C}$ in 2000 and $15.4{ }^{\circ} \mathrm{C}$ in 2001 , compared with a long-term average of $13.8^{\circ} \mathrm{C}$ (Table 1). Precipitation during the growing season was $276 \mathrm{~mm}$ in 2000 and 233 $\mathrm{mm}$ in 2001, compared with a long-term average (1971-2000) of $252 \mathrm{~mm}$. However precipitation in July 2000 was $30.6 \mathrm{~mm}$ higher than the long-term average, whereas the mean temperature in July 2001 was $18.9^{\circ} \mathrm{C}$, which was $2.8^{\circ} \mathrm{C}$ higher than normal. As a result, climatic conditions during the early weeks of July were wetter in 2000 and drier and much warmer in 2001 than the long-term average. Dry conditions in combination with above average daily temperatures $\left(19-22^{\circ} \mathrm{C}\right)$ during the first part of July resulted in water stress and retarded growth in 2001. However, good crop growth occurred in 2001 during late July and August when precipitation
Table 1. Deviation from long-term monthly mean temperature and precipitation at Jokioinen Meteorological Station in 2000 and 2001.

\begin{tabular}{lrrrr}
\hline & May & June & July & August \\
\hline $\begin{array}{l}\text { Mean temperature, }{ }^{\circ} \mathrm{C} \\
\quad\end{array}$ & 9.7 & 14.1 & 16.1 & 14.5 \\
$1970-2000$ & +0.7 & -0.3 & -0.5 & -0.3 \\
2000 & -1.0 & -0.6 & +2.8 & +0.9 \\
2001 & & & & \\
Precipitation, mm & 34 & 57 & 80 & 80 \\
$1970-2000$ & -7 & -6 & +31 & +4 \\
2000 & +3 & -5 & -7 & -10 \\
2001 & & & & \\
\hline
\end{tabular}

and temperatures were at the optimal level. More typical growing conditions occurred in 2000 despite the high precipitation in July.

Soil mineral nitrogen at a depth of $30 \mathrm{~cm}$ at planting was $13.4 \mathrm{~kg} \mathrm{NO}_{3}-\mathrm{N} \mathrm{ha}^{-1}$ and $5.2 \mathrm{~kg} \mathrm{NH}_{4}^{+}-$ $\mathrm{N} \mathrm{ha}^{-1}$ in 2000, and $19.3 \mathrm{~kg} \mathrm{NO}_{3}-\mathrm{N} \mathrm{ha}^{-1}$ and $7.5 \mathrm{~kg}$ $\mathrm{NH}_{4}^{+}-\mathrm{N} \mathrm{ha}^{-1}$ in 2001. Plant nitrogen uptake with no nitrogen fertilization, a crude indicator of soil nitrogen supply, was higher in 2001, at $60 \mathrm{~kg} \mathrm{~N} \mathrm{ha}^{-1}$, compared with $38 \mathrm{~kg} \mathrm{~N} \mathrm{ha}^{-1}$ in 2000 . On the basis of soil mineral nitrogen and plant nitrogen uptake in no-nitrogen plots, soil nitrogen supply was 57 , 117 and $177 \mathrm{~kg} \mathrm{~N}^{-1}$ in 2000 and 87, 147 and 207 $\mathrm{kg} \mathrm{N} \mathrm{ha}^{-1}$ in 2001, for the 0,60 and $120 \mathrm{~kg} \mathrm{~N} \mathrm{ha}^{-1}$ plots, respectively.

\section{Crop development and nitrogen uptake pattern}

The effects of nitrogen level during the season on the plant dry matter are shown in Figure 1a and Figure 2a. The changes during the season in the plant dry matter accumulation showed significant differences between the effects of nitrogen treatments in both years $(p<0.001)$. Differences between cultivars ( $p$ $<0.001)$ were significant only in 2000 , when cultivar Van Gogh had a higher dry matter content than Nicola throughout the season. The highest total dry matter content was generally reached using $120 \mathrm{~kg}$ $\mathrm{N} \mathrm{ha}^{-1}$. However, the differences between nitrogen levels of 60 and $120 \mathrm{~kg} \mathrm{~N} \mathrm{ha}^{-1}$ were significant only 
Vol. 19 (2010): 173-183.
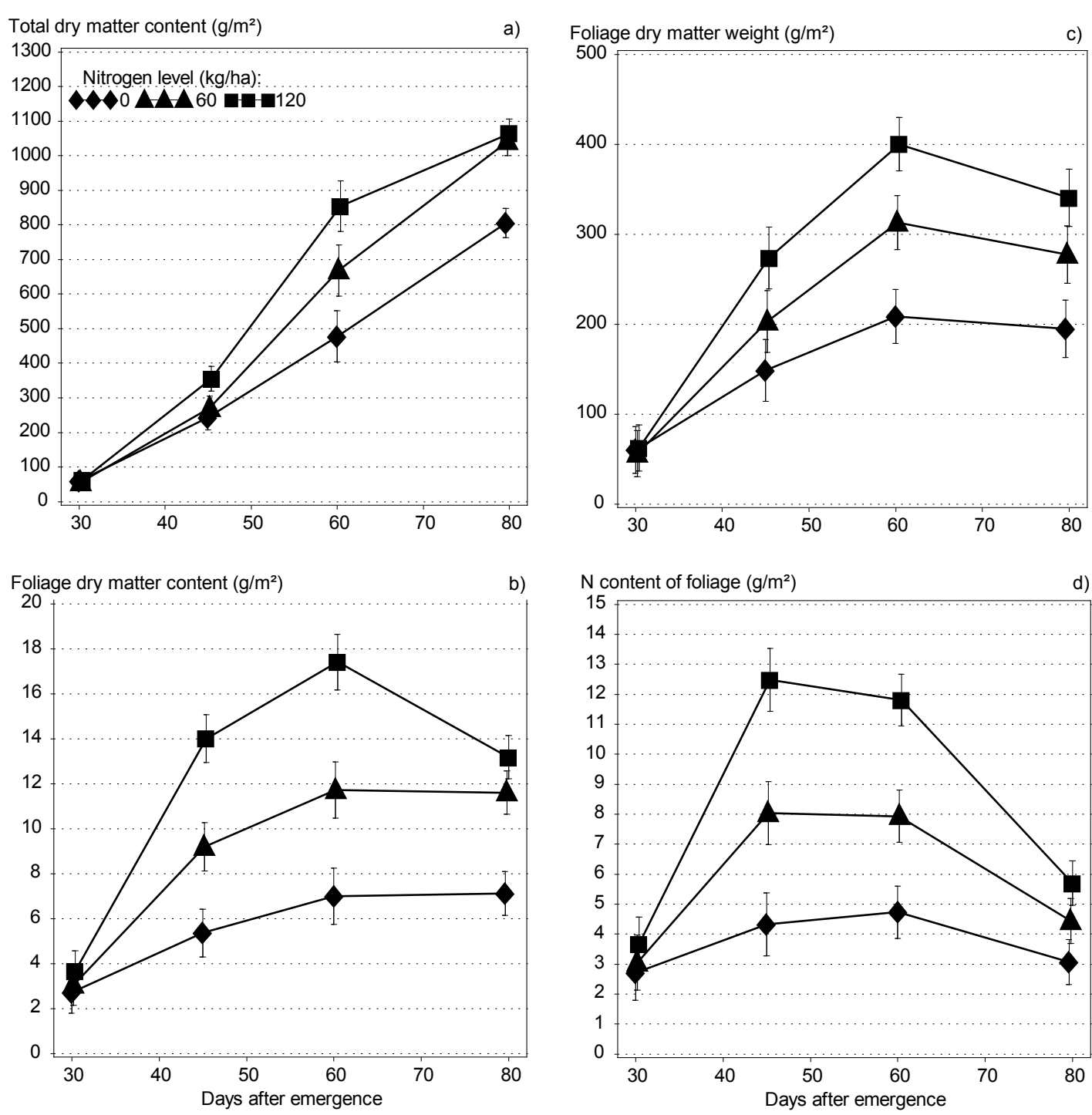

Figure 1. Changes during the season in potato crop development in 2000: a) total dry matter, b) foliage dry matter, c) total nitrogen content, d) nitrogen content of foliage. The graphs present estimated means and $95 \%$ confidence intervals for the mean.

at sampling dates $45 \mathrm{DAE}(p<0.001)$ and $60 \mathrm{DAE}$ $(p<0.01)$ in 2000 and during the second part of the growing season at sampling dates $45 \operatorname{DAE}(p$ $=0.05)$ and $60 \mathrm{DAE}(p<0.01)$ in 2001 .

The total plant nitrogen accumulation (Fig. 1 b and Fig. 2 b) was significantly increased with nitrogen applications $(p<0.001)$ in both years.
The greatest differences between nitrogen levels were noted during the period of rapid haulm growth 40-65 DAE. In 2001 the total plant nitrogen accumulation significantly increased $(p<0.001)$ between in the last two sampling times of the growing period. The opposite effect was found in 2000 when the plant nitrogen uptake decreased at the last 
Mustonen, L. et al. Nitrogen fertilization and yield formation of potato
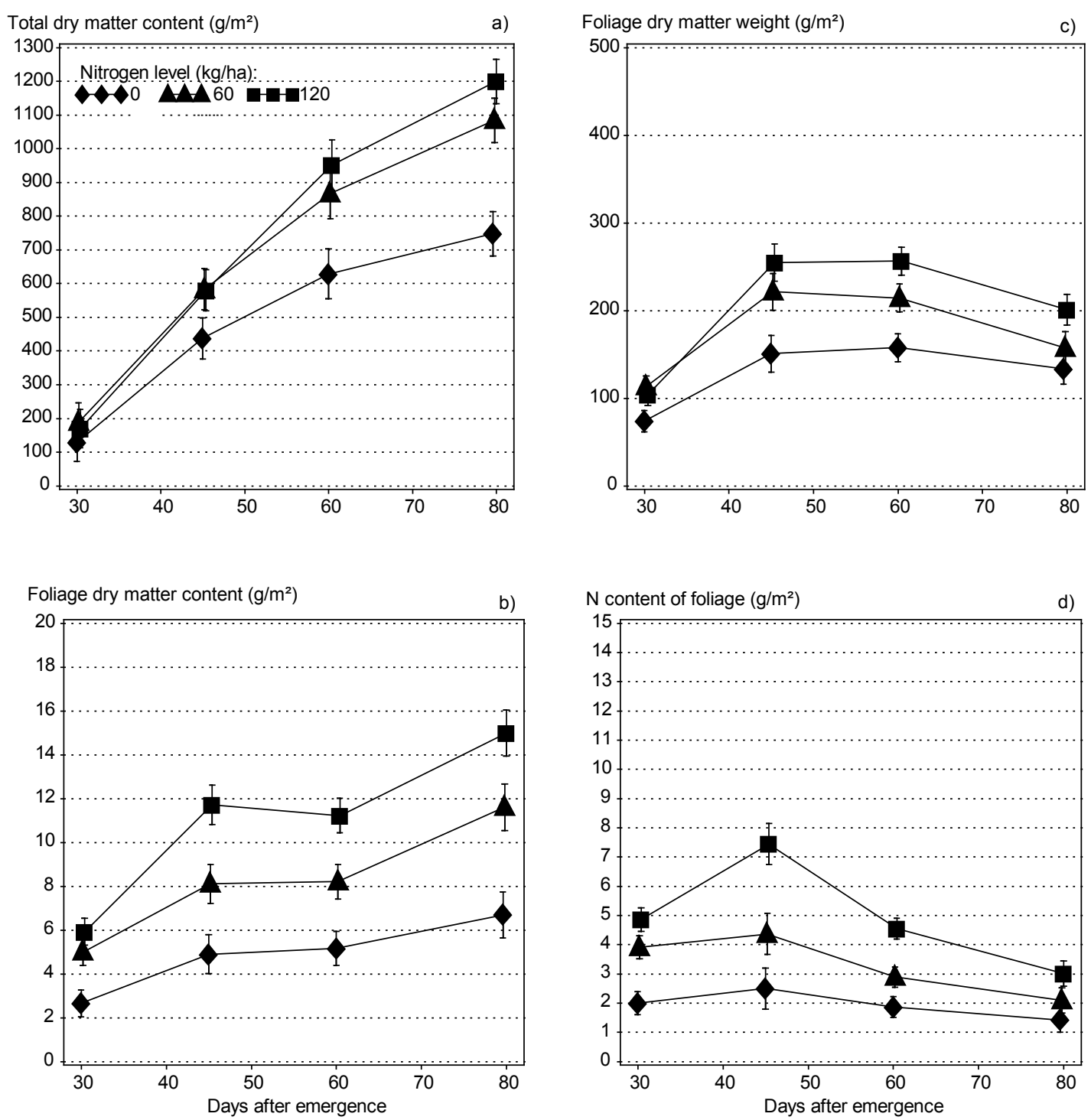

Figure 2. Changes during the season in potato crop development in 2001: a) total dry matter, b) foliage dry matter, c) total nitrogen content, d) nitrogen content of foliage. The graphs present estimated means and $95 \%$ confidence intervals for the mean.

sampling in August. The differences between years were due to differences in climatic conditions. The difference between cultivars was significant only in 2000 when Van Gogh showed higher $(p<0.001)$ total nitrogen uptake than Nicola. Van Gogh had significantly higher $(p<0.001)$ total plant nitrogen uptake than Nicola at $120 \mathrm{~kg} \mathrm{~N} \mathrm{ha}^{-1}$.
The nitrogen treatments strongly influenced the plant haulm dry matter accumulation and the nitrogen accumulation of the haulms to an even greater extent (Figures $1 \mathrm{c}-\mathrm{d}$ and Figures $2 \mathrm{c}-\mathrm{d}$ ). In 2000, except for the first sampling date, nitrogen levels had a significant effect on both dry matter $(p<0.001)$ and nitrogen accumulation of haulms 
Vol. 19 (2010): 173-183.

$(p<0.001)$. In 2001, in addition to other sampling dates, there were also significant differences between nitrogen level 0 and the other nitrogen levels $(p<0.001)$ at the sampling date 30 DAE. The dry matter and nitrogen that accumulated in haulms started to decline during the later part of the season and nitrogen was relocated to tubers. The internal relocation of dry matter and the nitrogen from haulms was similar for both cultivars and at all nitrogen levels and was similar in both trials. In 2001 Nicola had higher dry matter content of haulms than Van Gogh at the sampling date 60 DAE $(p<0.001)$. However in 2000, Van Gogh had significantly higher dry matter content $30 \mathrm{DAE}(p$ $<0.001)$ and $45 \operatorname{DAE}(p=0.04)$ and also higher haulm nitrogen content $30 \mathrm{DAE}(p<0.001)$. The amount of dry matter and nitrogen accumulation in haulms was substantially higher in 2000 compared with 2001. The differences between years were due to differences in climatic conditions.

In 2000 the effect of nitrogen (Figure 3a) on the tuber dry matter accumulation was significantly different between nitrogen levels 60 days after emergence in early August. Van Gogh had higher tuber dry matter content than Nicola at sampling dates $45 \operatorname{DAE}(p<0.001), 60 \mathrm{DAE}(p<0.001)$ and $80 \mathrm{DAE}(p<0.01)$. In 2001 the variation in tuber dry matter accumulation between 60 and $120 \mathrm{~kg}$ $\mathrm{N} \mathrm{ha}^{-1}$ was small during the first part of the season (Figure 3b) and a significant difference between nitrogen treatments $(p=0.02)$ was found only at the last sampling date in August. An opposite reaction of the cultivars was noted when Nicola had higher tuber dry matter content than Van Gogh at the last two sampling times in August. However, differences between cultivars were not statistically significant. The dry matter accumulation in tubers was generally much higher during the 2001 growing period.

\section{Tuber yield, dry matter and final nitrogen uptake}

Tuber yield generally increased with increasing nitrogen application rate, when tubers were harvested at maturity (Table 2). The main effects of nitrogen $(p<0.001)$ and cultivar $(p<0.05)$ were statistically significant, but there was no difference between
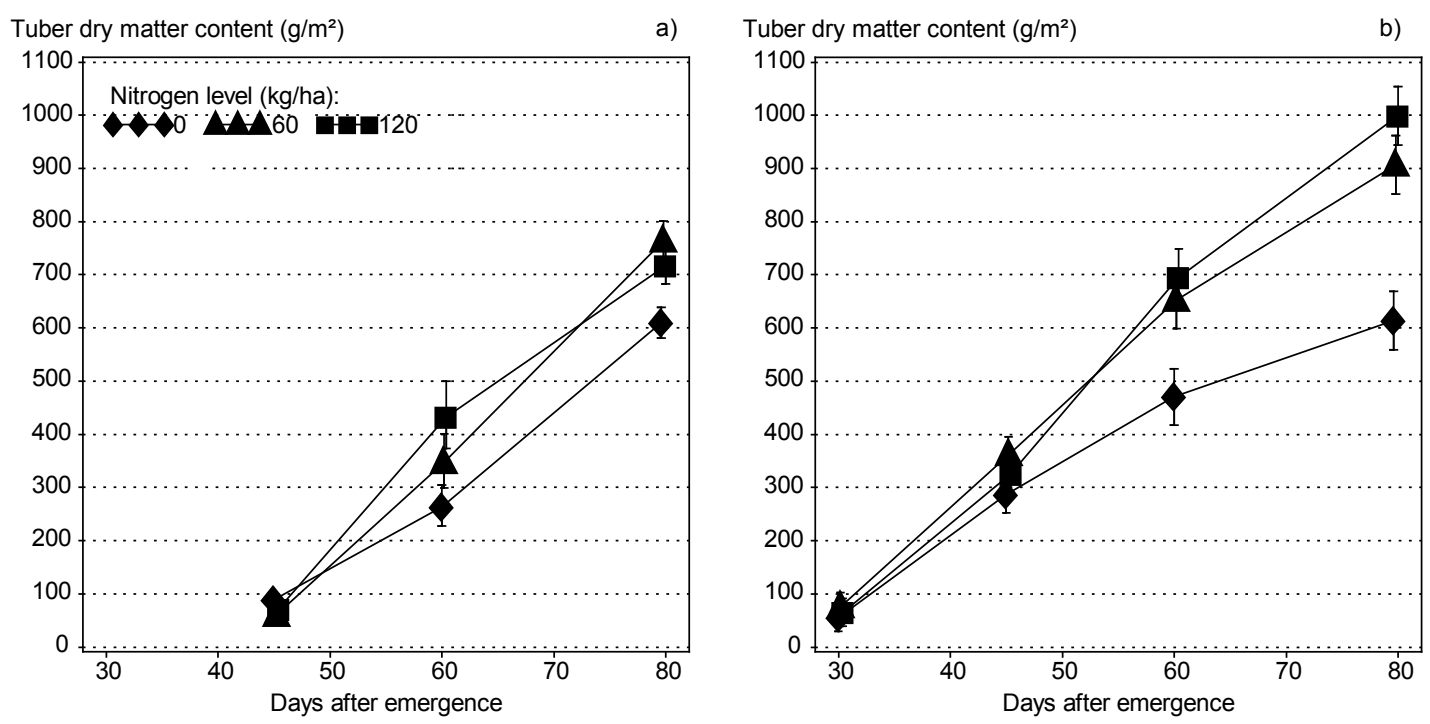

Figure 3. Changes during season in potato tuber dry matter content in 2000 (a) and 2001 (b). The graphs present estimated means and $95 \%$ confidence intervals for the mean. 
Mustonen, L. et al. Nitrogen fertilization and yield formation of potato

years in these effects. Cultivars reacted differently between years $(p<0.001)$, but there was a similar response of cultivars between nitrogen levels ( $p=$ 0.078). Non-significant year $\times$ nitrogen interaction indicated that nitrogen had a similar effect in both the trials. Van Gogh had significantly higher $(p<$ 0.001 ) yield than Nicola at the highest nitrogen application level in 2000 and respectively Nicola had significantly higher yield at all three fertilizer levels in $2001\left(0 \mathrm{~kg} \mathrm{~N} \mathrm{ha}^{-1}(p<0.05), 60 \mathrm{~kg} \mathrm{~N}^{-1}\right.$ $(p<0.001)$ and $120 \mathrm{~kg} \mathrm{~N} \mathrm{ha}^{-1}(p<0.001)$ in 2001).

As for tuber yield, nitrogen application significantly increased the plant dry matter accumulation (Table 2). Differences between cultivars and years were not significant and cultivars did not react differently to nitrogen applications. Statistically significant interactions were recorded for nitrogen $x$ year $(p<0.01)$ and cultivar $\times$ year $(p<0.01)$. The tuber dry matter accumulation was not significantly different between nitrogen application rates of 60 $\mathrm{kg} \mathrm{N} \mathrm{ha}^{-1}$ and $120 \mathrm{~kg} \mathrm{~N} \mathrm{ha}^{-1}$ for Nicola in 2000, but was more responsive to nitrogen fertilization in 2001.

Dry matter content in tubers declined with nitrogen fertilizer levels (Table 2). When cultivars were compared, it was significantly lower for the later-maturing Nicola. Dry matter content of tubers was also significantly higher $(p<0.001)$ in 2001 compared with 2000 , as a result of different climatic conditions between years.

The significant effects of nitrogen $(p<0.001)$ and year $(p<0.001)$ were found on the plant nitrogen uptake of tubers (Table 2). The main effect of cultivar was not significant, but the interaction between year and cultivar $(p=0.02)$ indicates that there were differences between cultivars only in 2000. Nitrogen accumulation of tubers was clearly higher in 2001 compared with 2000.

\section{Efficiency of nitrogen use}

Apparent fertilizer nitrogen recovery calculated for both years showed a tendency to decline at the high nitrogen fertilizer application level of $120 \mathrm{~kg} \mathrm{~N} \mathrm{ha}^{-1}$ (Table 3). The proportion of nitrogen recovered found in tubers increased between $80 \mathrm{DAE}$ and the final harvest in 2000 but not in 2001. Recoveries of nitrogen were much lower in 2000 than in the drier

Table 2. Effect of year, nitrogen application level and cultivar on tuber yield, plant dry matter accumulation and nitrogen accumulation in 2000-2001. Adjusted means within each year and treatment not followed by same letter are significantly different at $p \leq 0.05$.

\begin{tabular}{|c|c|c|c|c|c|}
\hline \multirow[t]{2}{*}{ Treatment } & \multicolumn{3}{|c|}{ N-level } & \multicolumn{2}{|c|}{ Cultivar } \\
\hline & 0 & 60 & 120 & Van Gogh & Nicola \\
\hline \multicolumn{6}{|c|}{ Tuber yield, $\mathrm{kg} / \mathrm{ha}^{-1}$} \\
\hline 2000 & $29.8^{\mathrm{a}}$ & $39.8^{\mathrm{b}}$ & $44.9^{\mathrm{c}}$ & $39.2^{\mathrm{a}}$ & $37.2^{\mathrm{b}}$ \\
\hline 2001 & $28.3^{\mathrm{a}}$ & $40.7^{\mathrm{b}}$ & $45.1^{\mathrm{c}}$ & $35.9^{\mathrm{b}}$ & $40.2^{\mathrm{a}}$ \\
\hline Mean & 29.1 & 40.3 & 45.0 & 37.5 & 38.7 \\
\hline \multicolumn{6}{|c|}{ Dry matter yield, $\mathrm{kg} / \mathrm{ha}^{-1}$} \\
\hline 2000 & $7.3^{\mathrm{a}}$ & $9.4^{\mathrm{b}}$ & $9.5^{\mathrm{b}}$ & $9.2^{\mathrm{a}}$ & $8.3^{\mathrm{b}}$ \\
\hline 2001 & $7.1^{\mathrm{a}}$ & $10.1^{\mathrm{b}}$ & $10.6^{\mathrm{c}}$ & $9.0^{\mathrm{b}}$ & $9.5^{\mathrm{a}}$ \\
\hline Mean & 7.2 & 9.7 & 10.1 & 9.1 & 8.9 \\
\hline \multicolumn{6}{|c|}{ Dry matter, $\%$} \\
\hline 2000 & $24.5^{\mathrm{a}}$ & $23.7^{\mathrm{b}}$ & $21.1^{\mathrm{c}}$ & $23.7^{\mathrm{a}}$ & $22.5^{\mathrm{b}}$ \\
\hline 2001 & $25.1^{\mathrm{a}}$ & $24.8^{\mathrm{a}}$ & $23.7^{\mathrm{b}}$ & $25.3^{\mathrm{a}}$ & $23.7^{\mathrm{b}}$ \\
\hline Mean & 24.8 & 24.2 & 22.4 & 24.5 & 23.1 \\
\hline \multicolumn{6}{|c|}{ N-uptake, $\mathrm{kg} / \mathrm{ha}^{-1}$} \\
\hline 2000 & $38.1^{\mathrm{a}}$ & $75.3^{\mathrm{b}}$ & $94.8^{\mathrm{c}}$ & $73.4^{\mathrm{a}}$ & $65.5^{\mathrm{b}}$ \\
\hline 2001 & $60.4^{\mathrm{a}}$ & $98.8^{\mathrm{b}}$ & $115.3^{\mathrm{c}}$ & $89.6^{\mathrm{a}}$ & $93.4^{\mathrm{a}}$ \\
\hline Mean & 49.3 & 87.1 & 105.1 & 81.5 & 79.4 \\
\hline
\end{tabular}


Vol. 19 (2010): 173-183.

Table 3. Effect of year, nitrogen application level and cultivar on the utilization of fertilizer nitrogen, the apparent nitrogen recovery $(\%)$, in potato haulm, tubers and total plant 80 days after emergence (DAE) and in tubers at maturity in 2000-2001.

\begin{tabular}{|c|c|c|c|c|c|c|c|c|}
\hline \multirow[t]{2}{*}{ Treatment } & \multicolumn{2}{|c|}{$\begin{array}{l}80 \text { DAE } \\
\text { Haulm }\end{array}$} & \multicolumn{2}{|c|}{$\begin{array}{c}80 \text { DAE } \\
\text { Tubers } \\
\end{array}$} & \multicolumn{2}{|c|}{$\begin{array}{c}80 \text { DAE } \\
\text { Total plant }\end{array}$} & \multicolumn{2}{|c|}{$\begin{array}{c}\text { Maturity } \\
\text { Tubers }\end{array}$} \\
\hline & 2000 & 2001 & 2000 & 2001 & 2000 & 2001 & 2000 & 2001 \\
\hline \multicolumn{9}{|c|}{$\mathrm{N}$ level, kg/ha ${ }^{-1}$} \\
\hline 60 & 20.2 & 11.1 & 52.1 & 64.2 & 72.4 & 75.4 & 64.0 & 61.9 \\
\hline 120 & 20.2 & 11.1 & 28.6 & 47.1 & 53.0 & 60.3 & 45.7 & 47.3 \\
\hline \multicolumn{9}{|l|}{ Cultivar } \\
\hline Van Gogh & 24.2 & 10.9 & 43.1 & 54.5 & $67 . .3$ & 65.4 & 53.3 & 59.2 \\
\hline Nicola & 20.4 & 13.5 & 37.5 & 56.7 & $57 . .9$ & 70.3 & 56.5 & 50.0 \\
\hline
\end{tabular}

2001. The average amount of nitrogen left in haulm residues 80 days after emergence was $11-24 \%$ of the total plant nitrogen, representing $26-42 \mathrm{~kg} \mathrm{~N} \mathrm{ha}^{-1}$.

\section{Discussion}

In 2001 climatic conditions ranged from near normal to low precipitation in combination with high daily temperatures, resulting in water stress during early July. On the other hand, optimal growth conditions during late July and August occurred in 2001. Differences in climatic conditions represent the normal variation between seasons that typically occurs in this region under non-irrigated conditions. Also many differences in crop reactions were caused by differences in the climatic conditions. The high soil fertility in 2001 is reflected in the higher soil mineral nitrogen in spring and higher soil nitrogen mineralization measured as the total nitrogen uptake of the unfertilized crop, and also the higher plant nitrogen accumulation in 2001 compared with 2000. Therefore, there was a significant effect of year on many traits reported in this study.

Nitrogen supply influences the development of potatoes by increasing the expansion rate of leaves, affecting the total amount of solar radiation intercepted and the partitioning of dry matter within the plant. Nitrogen itself has little effect on the amount of dry matter produced per unit of intercepted radiation (Millard and Marshall 1986). Differences between nitrogen levels in the plant dry matter accumulation were small during the first part of the season. Cultivars had similar genotypic reactions to nitrogen and only minor differences in the characteristics of the cultivars were established. The highest dry matter yield was generally obtained at a nitrogen supply of $120 \mathrm{~kg}$ $\mathrm{N} \mathrm{ha}^{-1}$. A high nitrogen application rate increased the period of maximum growth and increased the total haulm dry matter accumulation in particular. On the other hand, oversupply of nitrogen causes excessive growth of the foliage, resulting in too large a canopy for optimal tuber growth (Vos and Biemond 1992, Harris 1990). However, nitrogen supply needs to be sufficient to avoid a low level of light interception and reduced photosynthetic capacity. In the report of Allison et al. (1998) it was found that each unit of leaf area index needed a total uptake of $30-50 \mathrm{~kg} \mathrm{~N} \mathrm{ha}^{-1}$.

The official recommendations in Finland for nitrogen fertilizer application are very low (60$120 \mathrm{~kg} \mathrm{ha}^{-1}$ ) compared with the European levels (160-220 $\mathrm{kg} \mathrm{ha}^{-1}$ ) related to higher yield levels than those commonly obtained in Finland. In the short growing period characteristic of Finland, nitrogen levels must balanced between the potential yield and the date of harvest. The results in these experiments indicate that an application of only $60 \mathrm{~kg} \mathrm{~N} \mathrm{ha}^{-1}$ was sufficient to allow rapid ground cover development and so there was no reduction in yield until later in the season when the canopy started to senesce because of the low nitrogen supply. Similar findings regarding changes during the season in the accumulation of dry matter at different nitrogen levels were reported by Mil- 
Mustonen, L. et al. Nitrogen fertilization and yield formation of potato

lard and Marshall (1986) and Riley (2000). Both cultivars were medium early cultivars and were also of the determinative type of growth, partitioning the dry matter and nitrogen in a similar way into the haulms. Indeterminate varieties take more nitrogen from the soil and the accumulation of dry matter and nitrogen into haulms is greater and can be maintained for longer periods than in early maturing cultivars of the determinate type (Firman and Allen 1989 and Allison et al. 1998).

During early growth stages, potato plants take up nitrate at excessive levels and most of the plant nitrogen is accumulated in haulms (Millard and Marshall 1986, Vos 1999). In this study the nitrogen content of haulms started to decline 45 days after emergence and most of the nitrogen was relocated from haulms to tubers. In 2001 total plant nitrogen increased until late August on account of the high nitrogen supply following the water-stress period during the first part of the season.

Considering the results at maturity, tuber yield, plant dry matter and nitrogen accumulation were related to crop nitrogen supply. Although the high dose of $120 \mathrm{~kg} \mathrm{~N} \mathrm{ha}^{-1}$ significantly increased dry matter accumulation, the profit was not high because dry matter concentration in tubers declined by $2.6 \%$ in 2000 and by $1.1 \%$ in 2001 between 60 and $120 \mathrm{~kg} \mathrm{~N} \mathrm{ha}^{-1}$ application rates. During the limited growing period dry matter content corresponding with the high nitrogen application rates could not match the dry matter content associated with the lower nitrogen supply before the end of the growing season. The same effect of nitrogen levels on dry matter content has been reported in several European studies (Vos 1997, Riley 2000, and Hagman and Olsson 2006). There were significant interactions between cultivars and years in tuber yield, and between dry matter and nitrogen accumulation. This can be attributed to the differences in rainfall, suggesting that leaching losses may have occurred in July 2000 when rainfall was $30 \mathrm{~mm}$ above the long-term average. Also the period of high temperatures and water stress in 2001 may have caused genotypic reaction. Under these conditions Nicola proved to be more resistant to drought than Van Gogh. Dry matter accumulation clearly increased with increasing supply of nitrogen to the crop because nitrogen supply was no longer a limiting factor for dry matter accumulation.

Apparent fertilizer nitrogen recovery was calculated for tubers harvested 80 days after emergence when haulms started to senesce $(80-85 \%$ of leaf area) and when the plants had reached maturity. Recoveries were lower in the wet year of 2000 than in the dry year of 2001, probably as a result of $\mathrm{N}$ leaching occurring during the mid-late season in 2000 . The proportion of recovered fertilizer found in tubers clearly declined with increase in the level of the nitrogen supply. The recovery values $(53-75 \%)$ on a whole plant basis were similar in these experiments to those recorded in field trials conducted by Vos (1997) and Neeteson (1989). In Michigan, Joern and Vitosh (1995) reported lower recovery percentage of fertilizer nitrogen, ranging from $34 \%$ for tubers to $52 \%$ for the whole crop. In the study of Riley (2000) in Norway, recoveries ranged from $27-56 \%$ for tubers of early and semi-early cultivars. Kuisma (2002), in Finland, reported high nitrogen recoveries of $58-99 \%$ based on tuber analyses. The quantity of nitrogen left in the soil by crop residues ranged from $12-22 \%$ of that applied. This supports conclusions (Allison et al. 1998) that the potato crop does not necessarily leave large nitrogen residues in the soil after harvest.

Large amounts of fertilizer nitrogen represent a risk to quality and particularly to the environment. The results suggest that an application of only 60 $\mathrm{kg} \mathrm{N} \mathrm{ha}^{-1}$ was sufficient to allow rapid ground cover development and there were relatively small reductions in yield until late in the season compared with when nitrogen was applied at $120 \mathrm{~kg} \mathrm{~N} \mathrm{ha}^{-1}$. The nitrogen was accumulated during the first half of the season in haulms and relocated to tubers in significant amounts in the later part of the season. The results are consistent with previous findings in the region and the official base limits for fertilizer recommendations of $60-120 \mathrm{~kg} \mathrm{~N}^{-1}$ in Finland. 


\section{AGRICULTURAL AND FOOD SCIENCE}

Vol. 19 (2010): 173-183.

\section{References}

Allison, M.F., Allen, E.J. \& Fowler, J.H. 1998. The nutrition of the potato crop - a review for the British Potato Council. BPC, Oxford p. 1-79.

Biemond, H. \& Vos, J. 1992. Effects of nitrogen on the development and growth of the potato plant. 2 . The partitioning of dry matter, nitrogen and nitrate. Annals of Botany 70: 37-45.

Firman, D.M. \& Allen, E.J. 1988. Field measurements of photosynthetic rate of potatoes grown with different amounts of nitrogen fertilizer. Journal of Agricultural Science 111: 85-90.

Firman, D.M. \& Allen, E.J. 1989. Relationship between light interception, ground cover and leaf area index in potatoes. Journal of Agricultural Science 113: 355-359.

Firman, D.M., Obrien, P.J. \& Allen, E.J. 1995. Appearance and growth of individual leaves in the canopies of several potato cultivars. Journal of Agricultural Science 125: 379-394.

Gumpertz, M.L. \& Brownie, C. 1993. Repeated measures in randomized block and split-plot experiments. Canadian Journal of Forest Research 23: 625-639.

Hagman, J. \& Olsson, K. 2006. Ge rätt mängd kväve till matpotatis Viola: 111: 16-17. (in Swedish).

Harris, P.M. 1990. Effect of irrigation and fertilizer nitrogen on the growth, yield and light utilization of two contrasting potato cultivars. Abstracts of conference papers and posters of the 11th triennial conference of the EAPR, Edinburgh 8-13 July 1990. p.178-179.

Jarvis, S.C., Stockdale, E.A., Shepherd, M.A. \& Powlson, D.S. 1996. Nitrogen mineralization in temperate agricultural soils: processes and measurement. Advances in Agronomy 57: 187-235.

Joern, B.C. \& Vitosh, L.M. 1995. Influence of applied nitrogen on potato. Part 2: recovery and portioning of nitrogen. American Potato Journal 72:73-84.

MacDonald, A.J., Poulton, P.R., Powlson, D.S. \& Jenkinson, D.S. 1997. Effects of season, soil type and cropping on recoveries, residues and losses of $\mathrm{N}$-15-labelled fertilizer applied to arable crops in spring. Journal of Agricultural Science, 129: 125-124.
Kenward, M.G. \& Roger, J.H. 1997. Small sample inference for fixed effects from restricted maximum likelihood. Biometrics 53: 983-997.

Kuisma, P. 1995. Perunan typpilannoitus vaatii taitoa. Tuottava peruna 22: 19-23. (in Finnish).

Kuisma, P. 2002. Efficiency of split nitrogen fertilization with adjusted irrigation on potato. Agricultural and Food Science in Finland 11: 59-54.

Millard, P. \& Marshall, B. 1986. Growth, nitrogen uptake, partitioning within the potato (Solanum tuberosum L.) crop, in relation to nitrogen application. Journal of Agricultural Science 107: 421-429

Mustonen, L. 2004. Yield formation and quality characteristics of early potatoes during a short growing period. Agricultural and Food Science 13: 390-398.

Neeteson, J.J. 1989. Effect of reduced fertilizer nitrogen application rates on yield and nitrogen recovery of sugar beet and potato. Netherlands Journal of Agricultural Science 37:227-236.

Riley, H. 2000. Level and timing of nitrogen fertilizer application to early and semi-early potatoes (Solanum tuberosum L. ) grown with irrigation on light soils in Norway. Acta Agriculture Scandinavica 50: 122-134.

Vos, J. 1997. The nitrogen response of potato (Solanum tuberosum L.) in the field: nitrogen uptake and yield, harvest index and nitrogen concentration. Potato Research 40: 237-248.

Vos, J. 1999. Split nitrogen application in potato: effects on accumulation of nitrogen and dry matter in the crop and on the soil nitrogen budget. Journal of Agricultural Science 133: 263-274.

Vos, J. \& Biemond, H. 1992. Effects of nitrogen on the development and growth of the potato plant. 1. The leaf appearance, expansion growth, life spans of leaves and stem branching. Annals of Botany 70: 27-35

Sattelmacher, B., Klotz, F. \& Marschner, H. 1990. Influence of the nitrogen level on root growth and morphology of two potato varieties differing in nitrogen acquisition. Plant and soil 123: 131-137.

Zebarth, B.J., Tai, T., Tarn, R., de Jong, H. \& Milburn, P.H. 2003. Nitrogen use efficiency characteristic of commercial potato cultivars. Canadian Journal of Plant Science 84: $589-598$. 